LBL -30024

DE91 013772

\title{
Chromosomal Changes in Culfured Human Epithelial Cells Transformed by Low- and High-LET Radiation
}

\author{
Tracy Chui-hsu Yang, Laurie M. Craise, John C. Prioleau, \\ Martha R. Stampfer, and Johng S. Rhim \\ Cell and Molecular Biology Division \\ Lawrence Berkeley Laboratory \\ University of California \\ Berkeley, CA 94720 . USA
}

This work was supported by the Director, Office of Energy Research, Office of Health and Environmental Research, of the U.S. Department of Energy under Contract No. DE-AC03-76SF00098.

This report has been reproduced directly from the best available copy. 


\title{
CHROMOSOMAL CHANGES NN CULTURED HUMAN EPITHELIAL CELLS IRANSFORMED BY LOW- AND HIGH-LET RADLATION
}

\author{
Tracy Chui-hou Yang*, Laurie M. Craise*, John C. Prioleau*, \\ Martha R. Slampfer", and Johng S. Rhim** \\ -Cell and Molecular Biology Division, Lawrence Berkeley Laboratory, \\ University of Califomia, Berkeley, CA 94720 , U.S.A. \\ " Laboralory of Cellular and Molectuar Biology, National cancer Insticute. \\ Bethesda. MD 20892, U.S.A.
}

\begin{abstract}
For a better assessment of radiation risk in space, an understanding of the responses of human cells, especialiy the epithelial cells, to low- and high-LET radiacion is essential. In our laboratory, we have successfully developed techniques to study the neoplastic transformation of two human epithelial call systems by ionizing radiation. These cell systems are human mammary epithelial crils (H184B5) and human epidermal keratinocytes (HEK). Both cell lines ane immortal, anchorage dependent for growth, and nontumorigenic in athymic nude mice. Neoplastic transformusion was achieved by irradiating cells successively. Our results showed that radiogenic cell transformarion is a multistep process and that a single exposure of ionizing radiation can cause only one step of transformation. It requires, therefore, multihits to make human epithelial cells fully tumorigenic. Using a simple karyotyping method, we did etromosome analysis with cells cloned at various sages of transfiormation. We found no consistent large tenninal deletion of chromosomes in radiacion-induced transformants. Some changes of totai numbe: of chromosomes, however, were observed in the transformed cells. These transformants provide an unique oppornunity for further generic sudies at a molecular level.
\end{abstract}

\section{WTRODUCIION}

Carcinogenic effect of radiacion is of great concem for long-term manned spaceflight. Becanse of such concern, over the past several years, many investigators at various major laboratories have scodied the neoplastic transfomation of mammalian cells by ionizing radiation $/ 1-9 /$. The cell systems used for these sndies have been mainly modent cells. Alshough it is generally recognized that radiation carcinogenesis sutties with human epithelial cells are very much needed because of their direct relevance to radiacion risk assessment, the difficulies in culturing human epithelial cells and in transforming human cells in vitro with radiation have severely impeded the progress.

In our laboratory, two established human epithelial cell lines are available for radiation cell transformation studies, and we have successfully transformed both human mammary epithelial cells and human epidermal keratinocytes with ionizing radiation and have performed some chromosome analysis with the transformants. Experimental results of radiacion-induced cransformation of these human epithelial cells and the data obtained from recent chromosone sudies are given in this repor.

\section{METHODOLOGY}

\section{Cell. Systems}

Human mammary epithelial cells (H184BS) used for present studies were from ptimary cells trated with benzo(a)pyiene. They are immonai and nonaunotigenic and require medium enriched with growth facuss to grow /10. The human epidermal kerainocytes (HEK) were immortalized by a transfection of pSV3. neo /11\%. These HᄃKK cells have a flat epitheliad morphology, form monolayer with density intibition. show no anchorage ixdependent growth, and are nonumorigenic in athymic nude mice. 


\section{Intadiation of Cells}

For neoplascic transfomation soudies, the iradiation was done with a $250 \mathrm{kVp}$ Philips $X$-ray machine and heavy ions acceleraied ac BEVALAC in Laweoce Berteley Laboratory. The dosimetry and exposure condition for $X$ rays and heavy ions have been repored in denil $/ 12$.

\section{Cell Transfomation Assay}

The focus assay, similar to that for C3H1OT1/2 cells, was used to study morphological transformation of humar epidermal kerarinocytes. The anchorage independent growth was determined by plating cells into $0.33 \%$ agar medium, and colonies containing more than 50 cells were counted as transfomants. The amorigeric lest was done by injecring $10^{6}-10^{7}$ cells in $0,2 \mathrm{ml}$ serum free media subcutaneously on the back of nude mice. A result was considered as positive only when a nodule was formed at the sive of injection and continued to grow into a size greacer than $0.5 \mathrm{~cm}$ in diameter.

For uransformation sadies with humLan mammary epithelial cells in viro. log phase cells were imadiated and plated into dishes with enriched media (MCDB-170). At weekly interval, cells were subculared and part of the cell population was seeded into MEM containing $10 \%$ new boeth calf serum to select for growth variants. The tests for anchorage independent growth and for the turnorigenic capacily of cells were the same as that used for human epidemal kerainocytes.

\section{Chromosome Anaiysis}

A standard karyotyping method was used for obtaining chromosome spread of buman epithelinl cells 113/. Briefly, exponential growing cells were treated with $1.0 \mu \mathrm{g} / \mathrm{ml}$ Colcernid for $2.3 \mathrm{hrs}$, followed by a hypotonic ureament of $0.075 \mathrm{M}$ poenssium chloride for $20 \mathrm{~min}$, and then fixed with a solution of 3 parts methanol to 1 part glacial acid. After spreading the cells on a clean slide, the cells were air-dixed. A Wright's stain was used to stain the chromosome.

\section{RESULIS}

\section{Neoplastic Sell Transformation}

We have successfully transformed human manghiry epithelial cells from the stage of immortalization to the stage of anchorage independent growth. Figure I shows the sequence of stages of transformation. Immortalized cells (H184BS) were irradiated by $2.2 \mathrm{~Gy}$ of iron perieles ( $600 \mathrm{MeV} / \mathrm{u})$ and selected for growth variants in MEM supplemented with $10 \%$ senm. Growh variants were found at a frequency about $10^{-4}-10^{-3}$ per survivor, and were cloned. A growth rate comperison berween H184BS and 2 grown variant (H184BS-F5) is shown in Figure 2 In the MEM with H184B5 cells slowly died off. Although the growth variants ean prolifere well in the medium with less growth factors, they cannot grow in soft agar media. A second exposure of radiacion was found to be necessery 00 unafform these growth raciants into the next stage of progression, i.e., ancharage independent grown. The sequence of transformation stages appears to be definite. In spite of much effor, we have not ben able to transform H184BS cells. with a single exposure of radiation, into the stages of anchorage independent growth. Recenily we have obtained transformants, which can grow in soft agar media, by iradiaring the growth variants with 2.2 Gy iron beam $(600 \mathrm{MeV} / \mathrm{m})$. We are now in the process to test the tumorigericity of cells that grew in soft agar media and received adititional $22 \mathrm{~Gy}$ iron particles.

\begin{tabular}{|c|c|c|c|c|}
\hline $\mathrm{BaP}$ & radiation & matiotion & radiation & \\
\hline imay & cell line & $\begin{array}{l}\text { growth } \\
\text { variant }\end{array}$ & $\begin{array}{l}\text { growing in } \\
\text { soft agar }\end{array}$ & amorigric \\
\hline $\begin{array}{l}\text { - defined modium } \\
\text { wilh many } \\
\text { growth faccors }\end{array}$ & $\begin{array}{l}\text { - immortal } \\
\text { - defined medium } \\
\text { with many } \\
\text { growh factors }\end{array}$ & $\begin{array}{l}\text { - growing in } \\
\text { MEM wilh } \\
\text { 10\% serwn }\end{array}$ & $\begin{array}{l}\text { - archorage } \\
\text { independent } \\
\text { growth }\end{array}$ & $\begin{array}{l}-10^{6} \cdot 10^{7} \text { cells } \\
\text { injection in } \\
\text { athymic aode } \\
\text { mice }\end{array}$ \\
\hline
\end{tabular}

Even. The sequence of unasiomation of human mammary epithelial cells. There are ar least three steps involved in transforming H184BS ino tumarigenic by ionizing radiation. 


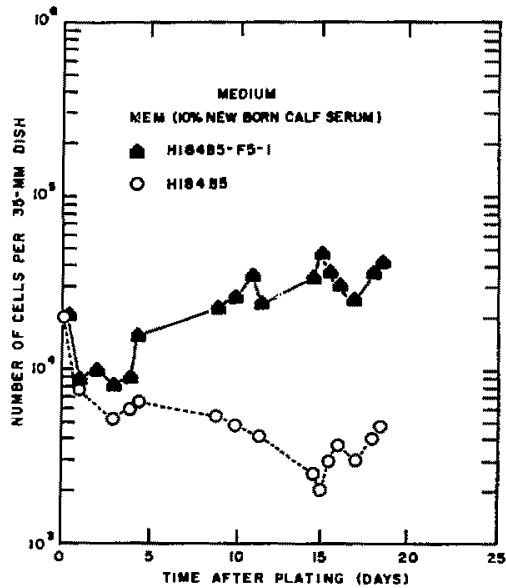

X9L. B93-7日2

Eig. 2. A comparison of growh in MEM between H184B5 and a growth variant (H184B5-F5).

Human epidemal keratinocyles immortalized by pSV3-neo can zow in regular MEM supplemented with serum and $2 \mu g / m l$ bydrocortisone. Ionizing radiation can cause morphological transformation of these sells. In general, afrer $5-6$ weeks incobacion, foci can be fourd in the dishes of irradianed cells. There is an extensive piling up of cells ir the focus, as shown in Figure 3. These transformed cells can grow in soft afar media, but do not forn a muncr in athymic nude mice. When these transformed cells were given another exposure of radiation, they became tumarigenic in nade mice, as shown in Figure 4. The sequence of stages of transformation for human epidermal keratinocytes is stown in Figure 5.

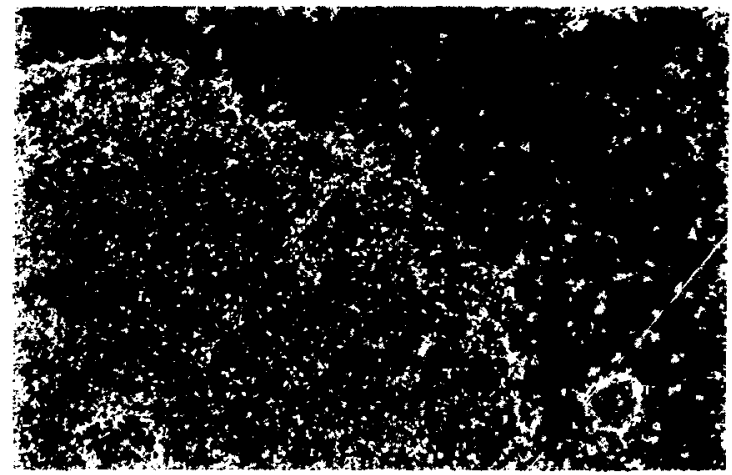

Eir. 3. A close-up picture of a transformed focus of human epidermal keratinocytes. There is extensive pilling up of cells in the focus. 


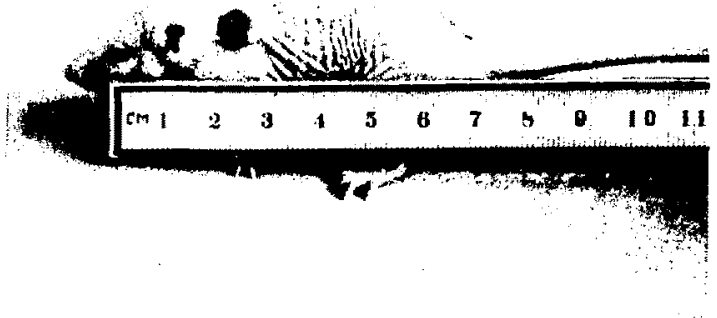

XBB $906-4905$

Eip. 4. A tumor formed in an athymic nude mice at the site of injection of transformed celis which first received $5 \mathrm{~Gy} X$ rays and then $2 \mathrm{~Gy}$ iron ions $(600 \mathrm{MeV} / \mathrm{u})$.

\begin{tabular}{|c|c|c|c|c|}
\hline \multirow[b]{2}{*}{ Primary culture } & $\begin{array}{l}\text { pSV/3-neo } \\
\text { transfection }\end{array}$ & radiation & radiation & \multirow[b]{2}{*}{ tumarigeric } \\
\hline & & $\rightarrow$ cell line & $\begin{array}{l}\text { growing in } \\
\text { soft agar }\end{array}$ & \\
\hline $\begin{array}{l}\text { - defined medium } \\
\text { with many } \\
\text { growth factors } \\
\text { - limited life span }\end{array}$ & & $\begin{array}{l}\text { - immortal } \\
\text { - growing in 10\%cs } \\
\text { MEM with } \\
\text { hydrocortisone } \\
\text { - densiry inhibicion } \\
\text { of growth }\end{array}$ & $\begin{array}{l}\text { - anchonge independent } \\
\text { growth } \\
\text { - higher growth rate }\end{array}$ & $\begin{array}{l}-10^{6} \cdot 10^{7} \text { cells } \\
\text { injection in } \\
\text { athymic nude } \\
\text { mice }\end{array}$ \\
\hline
\end{tabular}

Fin.5. The sequence of radiation transformation of human epidemal keratinocytes.

\section{Chromosome Analusis}

Using a simple karyotyping technique, we studied the chromosome changes in radiation transformed cells. Figure 6 shows a metaphnse spread of growth variants of human mammary epithelinl ceils. These chromosomes were stained by Wright's stain. There was a significant change of modat number of chromosomes in these transformed cells. Walen and Stampfer /14/ found that the modal number of chromosomes of H184BS cells was 47 with a very narrow range (46-48). Our results showed a significant decrease of modal number of chromosomes in the growth variants and a wide range (42-49) of chromosome numbers (Table I). 


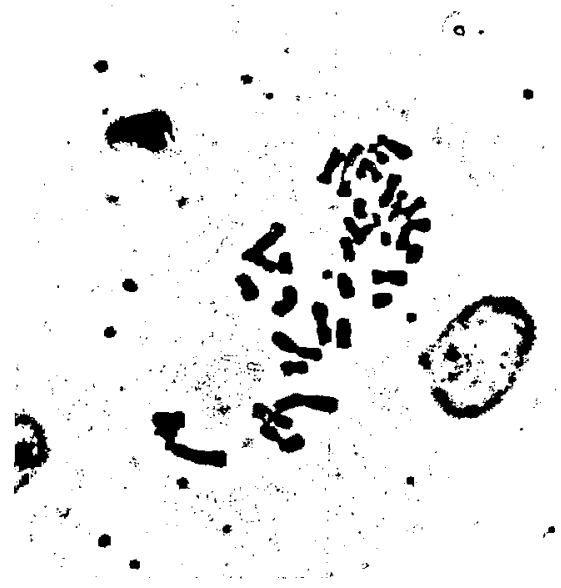

Eig.6. A melaphase spread of chromosomes of human mammary epithelial cells (H184BS-F5).

XBB $902-1252$

Table L Karyotype Analysis of Human Mammary Epithelial Cells

\begin{tabular}{|c|c|c|c|}
\hline Call & Growth Properties & Number of Chromosomes & Chromosome Aberrations \\
\hline H184E & normal; linited life span & 48 (diploid) & none \\
\hline H184B5 & $\begin{array}{l}\text { immortal; anchorage dependent: } \\
\text { growht factors enriched mediun }\end{array}$ & $47(46-48)$ & $\begin{array}{l}\operatorname{der}(4) t(1: 4)(q 23: q 35) \\
\operatorname{der}(8) t(1: 8)(q 24: q 24) \\
\operatorname{der}(10)(p 11) \\
\operatorname{der}(11) t(11: ?) \\
\operatorname{del}(17)(p 11) \\
\text { trisomy } \# 20\end{array}$ \\
\hline H184BS-F5 & $\begin{array}{l}\text { immortal; anchorage dependient: } \\
\text { MEM with } 10 \% \text { fetal calf serun }\end{array}$ & $45(42-49)$ & aneuploid \\
\hline
\end{tabular}

Human epidermal keratinocytes transformed by radiation wo various stages of progression were obtained and analyzed for chromosome changes. The modal number of chromosomes of these cells was found $w$ be 50 with a range from $49-50$ (Figure 7 ). Similar analysis was done for cells transformed by $X$ rays and/or heavy ions and experimental results are given in Table II. Compared with noniransformed cells (HEK), radiation i.ansformed kerntinocyles in general had less number of ehromosomes and a broader range, as shown in Figure 8. There was no large terminal delerion of chromosomes in transformed cells when the karyotype of these cells was examined (Figure 9). 


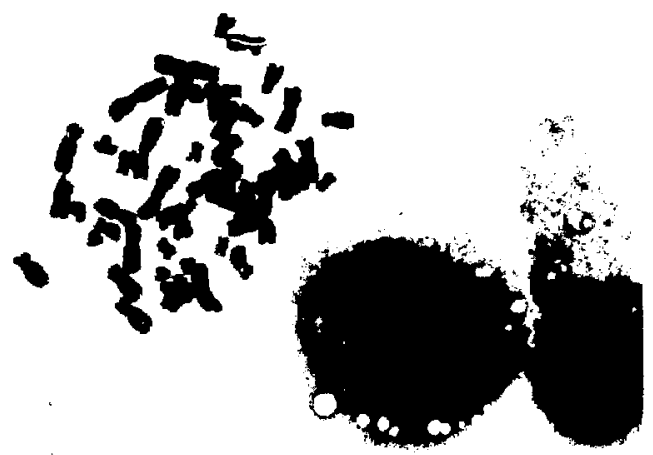

Eir.7. A chromosome spread of human epidermal keratinocytes inmoralized by pSV3-neo.

XBB $906-4793$

Table II. Karyorype Analysis of Human Epidermal Keratinocyzes

\begin{tabular}{|c|c|c|c|}
\hline Cell & Growth Properties & Number of ChromosomesiCell & $\%$ Cells \\
\hline HEX & inmortal; anchorage dependent growth & $\begin{array}{l}49 \\
50\end{array}$ & $\begin{array}{l}25.0 \\
75.0\end{array}$ \\
\hline HEK-A2 & growing in soft agar & $\begin{array}{l}41 \\
42 \\
43 \\
44 \\
45 \\
46 \\
47 \\
48 \\
51\end{array}$ & $\begin{array}{r}7.1 \\
7.1 \\
7.1 \\
7.1 \\
7.1 \\
14.3 \\
21.4 \\
21.4 \\
7.1\end{array}$ \\
\hline HEXK-A3-Fe & uunorigenic in nude mice & $\begin{array}{l}48 \\
49 \\
50\end{array}$ & $\begin{array}{l}20.0 \\
40.0 \\
40.0\end{array}$ \\
\hline HEK-Ar & growing in soft agar & $\begin{array}{l}47 \\
48\end{array}$ & $\begin{array}{l}16.7 \\
83.3\end{array}$ \\
\hline
\end{tabular}


CHROMOSOME NUMEER CHANGES IN HUMAN EPIOERMAL KERATINOCYTES TRANSFORMED DY IONIZING RADIATION

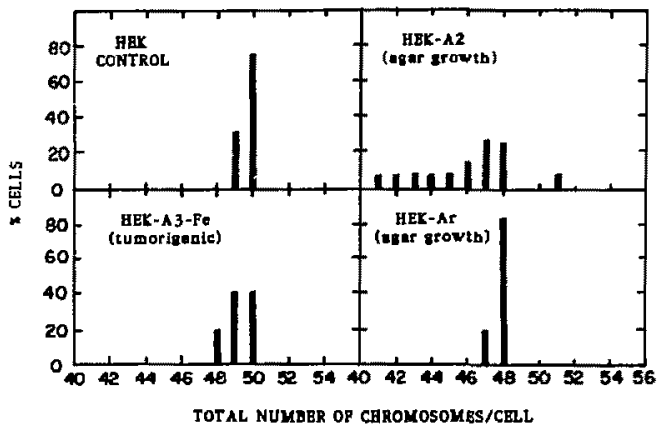

XBL $906-2233$

Eig. 8. Number of chromosomes in control and radiarion-transfomed henan epidenual kematinocytes.

\section{HUMAN EPIDERMAL KERATINOCYTES \\ IMMORTALIZED BY pSV3-neo}

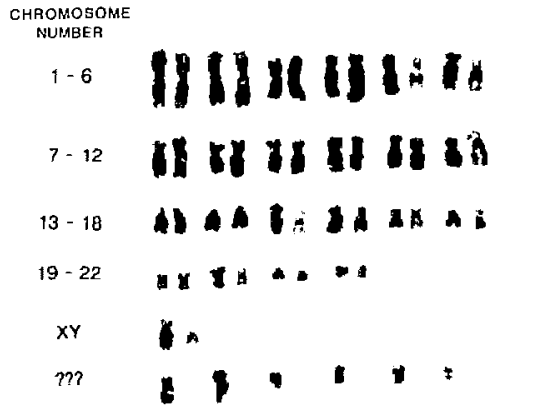

XBB 909-7907

Fig. 2. Karyoryping of control and transformed HEK cells: (A) control; 
HUMAN EPIDERMAL KERATINOCYTES

TRANSFORMED BY $X$ RAYS

(GROWING IN SOFT AGAR, NON-TUMORIGENIC)

CHOMOSOME

NUMBER
$1-6$
II $k>3 x$
$7-12$
1) 16 is 31 if 11
13-18 It
19-22 II $1 * \bullet$
xr
1
$m$
i.

XBB 909-7908

\section{HUMAN EPIDERMAL KERATINOCYTES \\ TRANSFORMED $B Y X$ RAYS \\ AND IRON PARTICLES (TUMORIGENIC)}

CHROMOSOME

NUMBEA

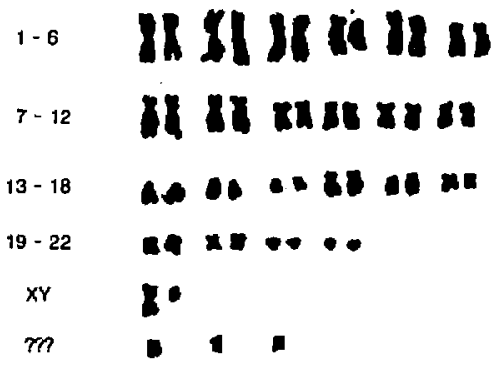

Eir. 2. Karyotyping of control and transformed HEK cells: (B) celts transformed by 5 Gy $X$ rays, growing in soft agar medin; (C) tumarigenic cells absined by giving 22 Gy iron particles ( $600 \mathrm{MeV} / \mathrm{u}$ ) to cells growing in soft agar mediz.

XBB $909-7909$ 
When astronauts travel in deep space for a long period of time, they will unavoidably receive a significant amount of cosmic rays, which consist of low- and high-LET radiation. Among various biological damages which can be induced by cosmic mys, the carcinogenic effect is of most concam. One of the important approaches to determine the porential cancinogenic effect of heavy ions is in viuro cell transformation. There are many advanages of using cultured cells to suxty the radiation carcinogenic effech including direct control of yarious factors which can suppress or enliance the carcinogenic processes $115 \%$. In general. the dala obtained from cell uansformation studies have been consistent with that frorn animal work, indicaling that a cellular change of growth behavior is essential for tumor development in vivo. In the past ten years, many studies have been done 10 determine the relative effectiveness of high-LET radiation in causing neoplastic transformation. Moss of these studies used rodent cells, including primary culures and cell lines. Although data from these experiments are valuable, it remains to be proved that human cells, especially epiuhelial cells which form most of the aumors in man, will respond to space radiation in a similar way. In view of this need, we have worked for several yenrs to develop the methods which can yield information on the carcinogenic effect of radiation in human epithelial cells. Our experimental results indicate that both human mammary epithelial cells immoralized by benzo(a)pyrene and human epidermal kerainocytes immortalized by pSV3-neo can be useful systems for saudying the neoplastic uransformation by radiacion.

Unlike many rodent cells, which can be transformed to umorigenic stage by a single radiation dose. human epithelial cells can only be transiomed one step after each exposure to radiation. There appears to be a definite sequence of steps in the multistage process of transfomation. The sequence of these steps are growth yariant, ancharage independent growth, and umorigenic. Our experimental results strongly suggest that multi hits are necessary for neoplastic transformation of human epilhelial cells by ionizing radiarion. This finding has an imponant implication for radiation risk assessment It suggests thar a single exposure to radiation is unlizely wo cause a nomal human cell wmorigenic and that procracted irradiation can be much more hazadous than acule exposure, In space, astronauts are exposed to radiacion chronically. The health risk of radiacion in space is, therefore, particularly important to know. However, if the total dose received during a spaceflight is small, e.g., one particie per cell nucleus, the chance that a normal human cell will be transformed to malignant stage will be very small if not zero. The effect of a small dose of space radiation, nevernheless, cannot be ignored, becalise in reality many of the cells in the body may have been initiaked already before the light by other physical or chemical carcinogens present in the environment. One furcher step change by radiation may be sufficient to make the cells amarigenic. For a given radiation dose, thus, the risk may be quite different for different individuals.

Shortly after the discovery of $X$ rays, the arcinogenic effect of radiation was noticed. Since then, the question how radiation causes cancer in man has been a major interest in radiobiology. With the success of cransforming human epithelial cells in vipo, we now have an unprecedented opportunity wo search for the answer at cell and molecular level. In our laboracory, we have just begun wo soudy systematically the genetic changes in transformed human epithelial cells. It has been shown that ionizing radiation, especially high-LET heavy ions, can cause large deletions in DNA. For this very reason, we did simple chromosome preparacions and expected to find some harge terminal delecion. Contrary to our expectation. the resuits showed no consistent large temoinal deletions in transformed cells. A decrease of ton chromosome number, however, was obtained in the transformants. The significance of the changes of votal chromosome number is unclear at present.

Because no banding of chromosome was done in these swodies, it is impossible to tell if there are any small detetions and translocations in the chromosomes. Further studies with these transformed cells should be done with chromosome banding technique and with molecular analysis to uncover the genetic changes important for radiation transformation.

\section{ACKNOWLEDGMENTS}

We would like to thank the BEVALAC crew for providing the heavy ion beams needed for these studies. The dosimetry and operation help from Dr. B. Ludewigt and other BioMed operators are highly appreciated. We also thank Dr. Marco Durante for his valuable heip in chromosome preparation. These suidies ware suppored by NASA (Contract \#T139M). 


\section{REFERENCES}

1. T.C. Yang, L.M. Craise, M. Mei and C.A. Tobias, Neoplestic transformation by heavy charged particles, Radiat Res. 104, S-177-S-187 (1985).

2. C.R. Geard, M. Georgeson and M. Tracisano, The mouse 3T3 cell transformation system: mechanistic and split dose studies with bigh and low LET radiation, Int. J. Radiar. Biol, 49, S18-S19 (1980).

3. J.B. Little, The radiobiology of in vitro neoplastic transformation, in: Radiarion Carcinogenesis and DNA Alterations, ed. FJ. Burns, A.C.Upton and G. Silini, NATO ASI Series. Life Sciences 124, 163. 184 (1986).

4. EJ. Hall and T.X. Hei, Oncogenic transformation with radiation and chemicals, Int. J. Radiar. Biol. 48, 1-18 (1985).

5. C. Borete, Radiarion oncogenesis in cell culnure, Adv. Cancer Res. 37. 159-232 (1982).

6. C.K. Hill, B.A. Carnes, A. Han and M.M. Ellind, Neoplastic transfomation is entanced by multiple low doses of tission-spectrum neutrons, Radiat. Res. 102, $404-410$ (1985).

7. R.C. Miller, C.R. Geard; D.J. Brenner, K. Komausu, S.A. Mirino and EJ. Hall, Neutron-energydependent oncogenic cransformation of C3H1OT1/2 monse cells, Radiax. Res. J17, 114-127 (1989).

8. M. Suzuki, M. Watanabe, $K$. Stratri, $K$. Nakano and I. Kaneko, Neoplastic cell transfomation by heavy ions, Radiar. Res. $120,468-476$ (1989).

9. M. Terzaghi-Howe, Induction of preneoplastic alteracions by $X$ rays and neucrons in exposed rat wacheas and isolated tracheal epithelial cells, Radiar. Res. 120, 352-363 (1989).

10. M.R. Stampfer and J.C. Barley, Induction of transformation and continoous cell lines from nomal human mammary epithelial cells afier exposure to benzo(a)pyrene, Proc. Nall. Acad Sci. USi 82, 2394 2398 (1985).

11. R. Gant, K.K. Sanford, R. Parshad, F.M. Price, W.D. Peterson, Jr. and J.S. Rhim, Enhanced G2 chromatid radiosensitivity, an early stage in the neoplastic transformation of human epidernal keratinocytes in culture, Cancer Res. 47, 1390-1397 (1987).

12. T.C. Yang and C.A. Tobias, Neoplastic cell transformation by energetic beavy ions and its modification with chemical agents, Adv. Space Res. 4, \#10, $207-218$ (i984).

13. R.S. Worton and C. Duf, Karyotyping, in: Cell Curure, ed. W.B. Jakoby and LH. Pastan. Academic Press, Inc., N.Y. 1979, pp. 322-344.

14. K.H. Walen and M.R. Stampfer. Chromosome analyses of human mammary epithelial cells at stages of chemical-induced transtormation progression to immonalicy, Cancer Genet Cytogenet 37, 249. 261 (1989).

15. T.C.H. Yang and C.A. Tobias, Radiation and cell transformation in vitro, Adv. in Biol. and Med. Phys. 17, 417-461 (1980). 